\title{
Efficient fuelwood consumption with innovative solar water-heating system for forest conservation and mitigation of household carbon emission
}

\author{
Lal Singh*, Maninder Jeet Kaur and D. K. Thakur \\ Himalayan Research Group Core Group, Department of Science and Technology (Government of India), Shimla 171 002, India
}

\begin{abstract}
The mountain population living in rural areas depends heavily on forests for daily needs of fuel, fodder, food and livelihood support activities. Regular collection of fuelwood for domestic needs of cooking, water and room heating, cattle-feed preparation, bathing, cleaning and washing is considered one of the major reasons for forest degradation, women drudgery and household carbon emissions. Alternative commercial sources of energy like LPG, electricity and kerosene oil fail to address the requirement of households in the temperate zone due to harsh winter conditions for 6-8 months in a year for demand of water and space heating. Therefore, the present study was initiated to install a locally designed, cost-effective solar water-heating systems with the aim of providing immediate clean energy solutions to the mountain households for water heating to achieve forest conservation, mitigate household carbon emission and women drudgery in fuelwood collection. Installation of 204 locally fabricated solar water-heating systems of $100 \mathrm{l} /$ day capacity was completed in two sites in Mandi and Kullu districts of Himachal Pradesh, India. Installation of these systems on an average achieved saving of $31.47 \%$ and $45.41 \%$ fuelwood at selected villages of Kullu and Mandi sites respectively. Maximum fuelwood saving through solar water heating was observed in the winter season. This resulted in timesaving for women, and visible improvement in their health and hygiene through availability of hot water. Fabrication of solar water-heating systems provided new skills and avenues to the rural artisans. This initiative of solar energy use in water heating has resulted in significant environmental, social and economic benefits.
\end{abstract}

Keywords: Carbon emission, fuelwood consumption, solar water-heating system, temperate forests.

\section{Introduction}

NoN commercial fuel extracted mainly from natural habitats (forests) as fuelwood is the main source of energy in

*For correspondence. (e-mail: lalhrg@gmail.com) domestic sector in the Himalayan mountains ${ }^{1}$. A study by Sood et $\mathrm{al}^{2}$ revealed that $93.3 \%$ of households used fuelwood for cooking and heating in Himachal Pradesh (HP). According to the 2011 Census, almost $85 \%$ of rural households in India are dependent on traditional biomass fuels. Harsh winter and cold climate round the year compel mountain households to use fire for $15-17 \mathrm{~h}$ for cooking, water and room heating in the temperate zone. Women and children toil hard to collect fuelwood which not only degrades natural forest ${ }^{3}$, but also affects the health of women and children. According to the World Health Organization, indoor air pollution which is referred to as 'killer in the kitchen' is responsible for 1.6 million deaths per year ${ }^{4}$. Temperate zone of the Himalaya is rich in forest resources. Independent studies of this region for forest dependence of local communities and commercial needs for timber, fuelwood, non-timber forest products (NTFPs), grazing and fodder extraction are limited. Most of the studies conducted on forest resource utilization, e.g. fuelwood collection are for different altitudinal zones ${ }^{5-7}$. Temperate zone is the most exploited region of the forests for different domestic and commercial needs, and efforts for regeneration, plantation and enrichment are comparatively less due to high altitude and difficult access in most parts for the field agencies. Keeping in view this background, exclusive activity of installing artisan-fabricated solar water-heating systems was designed for this zone to achieve twin benefits of reducing consumption of fuelwood in domestic waterheating and providing respite to the women and children in the collection of fuelwood. Water-heating activity intervention was selected on the basis of regular requirement throughout the year according to feedback from the household members. Poor economic conditions, complicated post-installation maintenance and damage due to freezing of commercially available solar water-heating systems were mentioned as main barriers for the acceptability of these systems ${ }^{8}$. Artisan-fabricated mountain solar water-heating systems were specially designed to overcome these challenges with the help from the Department of Science and Technology Core Support Programme of Science for Equity Empowerment and 
Development (SEED) Division at the Himalayan Research Group (HRG), Shimla, HP. The system was evaluated for working performance, safety, maintenance and requirements of rural households. It was observed to be cost-effective with utilization of local materials and skill for fabrication, anti-freezing outlet, providing 15 181 of boiling hot water maximum at $90^{\circ} \mathrm{C}$ within the first solar illumination of $30-35 \mathrm{~min}$ in the morning. Successive batches of hot water are available in 15-20 min gap. This system locally branded as 'Solar Hamam' and in 2018 was awarded the HP State Innovation Award for 2016-17 by the HP State Innovation Council. This article describes the installation of locally fabricated mountain solar water-heating system in different villages of Mandi and Kullu districts, HP, with saving of fuelwood for desired forest conservation and household carbon emission mitigation.

\section{Literature review}

Forestry contribution is $1.7 \%$ of nation's gross domestic product and does not take into account unrecorded withdrawals (NTFPs, fuelwood, fodder, etc.). The percentage of population using fuelwood is higher in rural areas (67.3) and then in urban and semi urban areas $(14 \%)^{9}$ which contributes to more than $93 \%$ of Greenhouse Gases (GHGs) emissions from the forestry sectors in India ${ }^{10}$. Holdren and Smith $^{11}$ estimated that $80 \%$ of rural households in India use unprocessed solid biomass such as wood, dung and agricultural residues for domestic cooking and room heating. Women approximately spend more than $274 \mathrm{~h}$ in a year for collecting fuelwood ${ }^{12}$. The annual fuelwood consumption by 854 million people in India is 216.4 million tonnes per year ${ }^{13}$. Per capita annual consumption of wood in various parts of the Himalaya ranges between 400 and $1500 \mathrm{~kg}$ fresh wt, which is much higher than other parts of India ${ }^{14-16}$. Fuelwood consumption is highest $(2.80 \mathrm{~kg}$ per capita/day) in areas above $2000 \mathrm{~m}$ altitude, and decreases with decrease in altitude ${ }^{5}$. Moreover, the environmental benefits of forests also remain to be quantified and calculated ${ }^{17}$. The World Bank ${ }^{18}$ estimated $18.5 \%$ of the 1.3 billion people living on 'environmentally fragile lands', including arid zones, slopes and forest ecosystems suffer from extreme poverty, located in remote areas and often in relatively inaccessible upland and hilly areas, where the reach to new technology and market progress is inhibited or slowed. To address these linkages, networking of rural livelihoods and forests is important to maintain and strengthen diverse livelihood options with convergence with other sectors and extra-sectoral factors. These options include increased agricultural productivity with value-addition, off-farm and non-farm employment opportunities, use of clean resources of energy with enabling conditions in marginal areas to reduce the pressure on forests with increased possibilities for pro-poor outcomes ${ }^{19-21}$. The proposed study was planned on this theme for which fuelwood consumption in two valleys of HP was studied for domestic use and saving with installation of innovative mountain solar water-heating system.

Studies on fuelwood were mainly aimed to estimate consumption at different altitudes across different socioeconomic and farm categories ${ }^{22,23}$. Maximum studies of this type and on fuelwood were conducted in Uttarakhand Himalaya ${ }^{6}$. However, studies on fuelwood consumption only in the temperate zone with installation of artisanfabricated mountain solar water-heating systems in rural mountain households for efficient consumption of fuelwood with $\mathrm{CO}_{2}$ emission mitigation target are lacking. Solar energy is the only clean energy solution to optimize use of fuelwood in forest-rich temperate zone households. Commercial solar water-heating systems are mainly designed for large Govt and private concerns like hospitals, institutions, hotels, etc. and are not suitable for rural households. High cost, low purchasing power, small capacity requirement, technical problems associated with freezing in the cold regions, difficulty in installation on sloping roof, lack of piped supply, quality of water particularly presence of silt and hardness - are some of the major deterrents in the popularization of commercial solar water-heating design ${ }^{8}$.

These factors were taken care while developing the system installed in 204 households of Dhlair village, Kurpan Valley, Kullu (107) and Rewnsi village and adjoining hamlets in Junee Valley, Mandi (97) during 2017-18. The third site of Dhodra Kawar under Shimla district was also included with installation of $100 \mathrm{such}$ solar water-heating systems.

\section{Materials and methodology}

This study was conducted from April 2017 to March 2018 in two valleys of Mandi and Kullu districts. In Kullu, the site was situated at Dhlair village $\left(31^{\circ} 58.187 \mathrm{~N}, 77^{\circ} 68.903 \mathrm{E}\right)$ in Kurpan valley of Nirmand block at an altitude of $2200 \mathrm{~m}$ amsl. In Mandi district, the study was carried out at Rewnsi village $\left(31^{\circ} 30.409 \mathrm{~N}\right.$, $77^{\circ} 04.745 \mathrm{E}$ ) at an altitude of $2000 \mathrm{~m}$ amsl and adjoining hamlets in Junee valley under Chachiot Block. These two sites are on the banks of the Satluj and Beas respectively. At each site, 100 households were involved in different activities under the National Mission of Himalayan Studies (NMHS) project and a third valley at Dhodhra Kawar, Shimla district was included to generate similar information. Initially, 33 out of 100 households involved were selected for collection of primary demographic and fuelwood utilization information for the study. Structured questionnaire was prepared and used to gather information on fuelwood collection, consumption and demographic details of households. Fuelwood consumption was 
recorded for $24 \mathrm{~h}$ with pre-weight survey method ${ }^{24}$. Annual deforestation rate per household and emission of carbon dioxide per annum as a result of fuelwood burning were also estimated. Fuelwood data were changed to cubic metre by dividing the mass unit of expansion ratio 1.90 (ref. 25). Total carbon emission was calculated by multiplying quantity of fuelwood burnt (ton dry mass, $\mathrm{t} \mathrm{dm}$ ) by the fraction of oxidized biomass and biomass carbon content $(\mathrm{t} \mathrm{C} / \mathrm{t} \mathrm{dm})$. As explained in $\mathrm{IPCC}^{26}$, default value of 0.9 was used as the fraction of biomass oxidized. Conversion of woody biomass factor of $0.5 \mathrm{t}$ $\mathrm{C} / \mathrm{t} \mathrm{dm}$ was used as explained with the eq. (1)

$$
\mathrm{Ct}=\mathrm{Mt} \times \mathrm{Mf}
$$

where $\mathrm{Ct}$ is the total biomass burn, Mt the fraction of biomass oxidized (0.9) and $\mathrm{Mf}$ is the woody biomass carbon content $(0.5 \mathrm{t} \mathrm{C/t} \mathrm{dm})$.

Emission of $\mathrm{CO}_{2}$ from fuelwood burning was calculated by conversion of total carbon content $(\mathrm{tC})$ to $\mathrm{CO}_{2}$ $\left(\mathrm{tCO}_{2}\right)$ using conversion ratio of $44 \mathrm{t} \quad \mathrm{CO}_{2} / 12 \mathrm{tC}$ as explained in the eq. $(2)^{26}$

$$
\mathrm{CO}_{2}=\mathrm{Mt} \times \mathrm{Mf} \times \mathrm{Mc} \times(44 / 12) .
$$

The mountain solar water-heating system was designed using local materials with involvement of rural artisans (carpenters and plumbers). This system is of dimensions $180 \mathrm{~cm} \times 90 \mathrm{~cm}$ (Figure 1). The outer frame was built of wood. Absorber sheet was made with galvanized iron sheet. Absorber sheet was insulated with thermocol on the back and the sun-facing side was fixed with specially designed aluminium alloy water coil of 18.01 capacity. Absorber sheet and water coil were coated with normal black paint containing amendments to absorb solar energy. Sun-facing side of the system was glazed with ordinary $3.5 \mathrm{~mm}$ window glass. The system was designed, developed, installed and evaluated prior to the programme

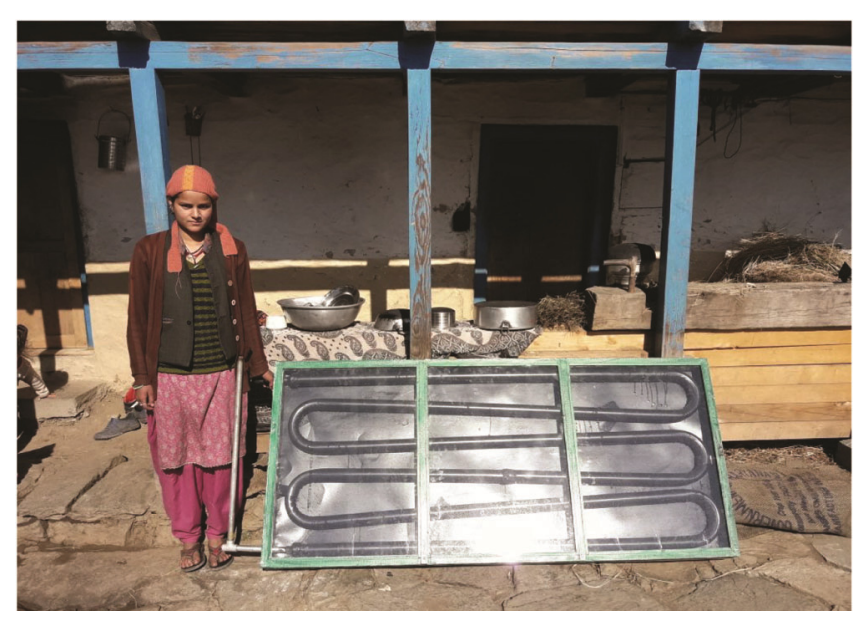

Figure 1. Mountain solar water-heating system in a rural household. under SEED, Division of the Department of Science and Technology, Government of India. Till date, 204 units of this system have been installed under NMHS supported project in HP. The system was designed to work in subzero conditions with specially designed anti-freezing valve for night-time drainage to avoid pipe cracking as faced in commercial solar water-heating systems. It was also designed for manual filling of cold water as most of the rural households lack indoor connections.

\section{Results and discussion}

Fuelwood is one of the daily needs of mountain people for cooking, water heating and room heating. Tree and shrub species from the forests are collected by the households on a regular basis. Dividing households to nuclear families and other developmental activities have put pressure on fuel and other resources in the mountains. The present study aims to identify utilization pattern and efficient usage with technology intervention for forest conservation and mitigation of household carbon emission in temperate Himachal Himalaya.

\section{Demography, fuelwood collection and utilization}

Table 1 presents the household attributes of demographic details with fuelwood dependency parameters. All households were reported to own agricultural lands with extended family set-up; in actual, almost all were nuclear families with average family size of 4.5 and 3.67 at Kullu and Mandi sites respectively. Surveyed villages were well-connected with village roads. Analysis of household income by source revealed that agriculture, horticulture, livestock, local enterprise, Government and private employment were the main sectors which contributed to the household income at the two study sites. Household income of Rs 101,969.70 and Rs 140,848.48 was estimated at Kullu and Mandi sites respectively. In agriculture, vegetable cash crops and apple in horticulture were the main source of income for the households surveyed. Both houses and standard of living were comparatively better in households of Mandi compared to Kullu with almost $78 \%$ pucca houses, whereas Kullu site had $82 \%$ mixed houses. Average land-holding size per household was almost equal ( $0.5 \mathrm{ha})$ on both sites, which was $100 \%$ nonirrigated.

\section{Seasonal fuelwood collection and utilization}

Kullu site being $200 \mathrm{~m}$ higher in altitude was observed to consume $5182.71 \mathrm{~kg}$ fuelwood/annum/household $(1514.67 \mathrm{~kg}$ summer, $2146.08 \mathrm{~kg}$ winter and $1521.96 \mathrm{~kg}$ monsoon). Mandi site households were reported to consume $3773.02 \mathrm{~kg}$ fuelwood/annum/household (605.94 kg 
Table 1. Demography, fuelwood collection and utilization

\begin{tabular}{lrr}
\hline & $\begin{array}{c}\text { Dhlair, Jhlair } \\
\text { Kurpan Valley, Kullu }\end{array}$ & $\begin{array}{c}\text { Rewnsi, Mulhas, Budragh } \\
\text { Junee Valley, Mandi }\end{array}$ \\
\cline { 2 - 3 } Parameters & Mean \pm SE & Mean \pm SE \\
\hline Average family size (persons) & $4.50 \pm 0.15$ & $3.67 \pm 0.45$ \\
Total land area (ha) & $0.49 \pm 0.54$ & $0.48 \pm 1.22$ \\
Income per household (HH) per month (Rs) & $101,969.70 \pm 9,409.5$ & $140,848.48 \pm 17,093.44$ \\
Distance of HH from road (km) & $13.63 \pm 0.46$ & $1.00 \pm 0.00$ \\
No. of trips/month for fuelwood collection & $12.63 \pm 0.43$ & $8.12 \pm 0.44$ \\
Amount of fuelwood consumption per day for & & $7.55 \pm 0.61$ \\
$\quad$ cooking (kg) & $3.67 \pm 0.12$ & $3.22 \pm 0.15$ \\
Distance travelled for fuelwood collection (km) & $3.76 \pm 0.12$ & $4.35 \pm 0.42$ \\
Time spent for fuelwood collection (h) & & \\
\hline
\end{tabular}

Source: HRG survey 2017-2018.

Table 2. Fuelwood consumption in different seasons

\begin{tabular}{|c|c|c|c|c|}
\hline \multirow[b]{2}{*}{ Season } & \multicolumn{2}{|c|}{ Dhlair Jhlair Kurpan Valley, Nirmand, Kullu } & \multicolumn{2}{|c|}{ Rewnsi, Mulhas, Budragh Junee Valley, Chachiot, Mandi } \\
\hline & $\begin{array}{c}\text { Fuelwood } \\
\text { consumption/HH/day }(\mathrm{kg})\end{array}$ & $\begin{array}{c}\text { Fuelwood } \\
\text { consumed/HH/Annum }(\mathrm{kg})\end{array}$ & $\begin{array}{c}\text { Fuelwood } \\
\text { consumption/HH/day }(\mathrm{kg})\end{array}$ & $\begin{array}{c}\text { Fuelwood } \\
\text { consumed/HH/annum }(\mathrm{kg})\end{array}$ \\
\hline Summer & $12.45 \pm 0.81$ & 1514.67 & $4.94 \pm 0.50$ & 605.94 \\
\hline Winter & $17.64 \pm 0.96$ & 2146.08 & $16.85 \pm 0.87$ & 2066.82 \\
\hline Monsoon & $12.51 \pm 0.98$ & 1521.96 & $8.97 \pm 0.59$ & 1100.26 \\
\hline Total & & 5182.71 & & 3773.02 \\
\hline
\end{tabular}

Source: HRG survey 2017-2018.

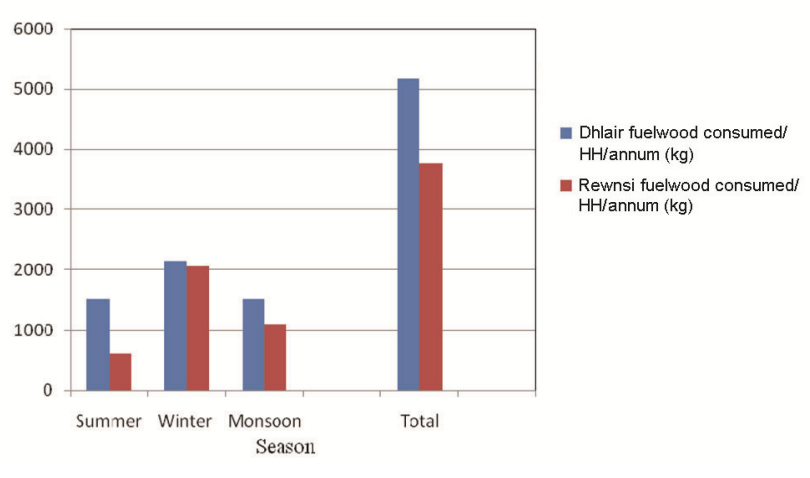

Figure 2. Fuelwood consumption in three seasons.

summer, $2066.82 \mathrm{~kg}$ winter and $1100.26 \mathrm{~kg}$ monsoon). Consumption was almost equal for summer and monsoon at Kullu site, but at Mandi site, there were significant variations in these seasons (Table 2 and Figure 2).

Consumption of fuelwood $\mathrm{kg} /$ household/day was different for different households depending on family size, economic standard and occupational status. Maximum fuelwood consumed (17.64 $\pm 0.96 \mathrm{~kg} /$ day/household) was in winter and followed by monsoon $(12.51 \pm 0.98 \mathrm{~kg} / \mathrm{day} /$ household) and summer (12.45 $\pm 0.81 \mathrm{~kg} / \mathrm{day} /$ household) at Kullu site. Consumption of fuelwood at Mandi site (16.85 $\pm 0.87 \mathrm{~kg} /$ day/household) in winter was maximum followed by monsoon $(8.97 \pm 0.59)$ and summer $(4.94 \pm$ 0.50 ). Consumption at Mandi site was $25-26 \%$ less in comparison to Kullu site in the same season. The species used for fuelwood at both the sites included Picea smithiana, Quercus leucotrichophora, Quercus dialatata, Cedrus deodara, Pinus wallichiana and Rhododendron arborium and apple prunings. Table 2 and Figure 2 present primary data collected for total, seasonal and per day consumption of fuelwood.

Consumption of fuelwood estimated was more or less similar to earlier studies in the Himalayan mountains ${ }^{27}$, but was comparatively higher than the reported $14.65 \mathrm{~kg}$ household $/$ day $^{28}$ and $14.65 \mathrm{~kg}$ household/day (ref. 24) for Garhwal Hiamalaya. Use of more fuelwood at Kullu site was attributed to site location. Mandi site is west-facing and receives sunlight for maximum duration in the day. However, Kullu site is east-facing and receives less sunlight during the day, needing to light the fireplace early in the day. Further Kullu site is close to the Bashleo pass which remains covered with snow till late June, keeping temperature low during morning and evening in summer as well.

\section{Fuelwood saving with mountain solar water-heating system installation}

Installation of locally fabricated mountain solar-water heating systems in 204 households of two sites resulted in significant saving of fuelwood. Table 3 and Figure 3 provide details of fuelwood saved in $\mathrm{kg} /$ day/household and 
Table 3. Fuelwood saving with mountain solar water-heating system installation

\begin{tabular}{|c|c|c|c|c|}
\hline \multirow[b]{2}{*}{ Season } & \multicolumn{2}{|c|}{ Dhlair Jhlair Kurpan Valley, Nirmand Kullu } & \multicolumn{2}{|c|}{ Rewnsi, Mulhas, Budragh Junee Valley, Chachiot, Mandi } \\
\hline & $\begin{array}{c}\text { Fuelwood saved/HH/day } \\
\quad(\mathrm{kg}) \text { with solar } \\
\text { water-heating system }\end{array}$ & $\begin{array}{l}\text { Fuelwood saved/HH/annum } \\
\text { (kg) with solar } \\
\text { water-heating system }\end{array}$ & $\begin{array}{c}\text { Fuelwood saved/HH/day } \\
\qquad(\mathrm{kg}) \text { with solar } \\
\text { water-heating system }\end{array}$ & $\begin{array}{l}\text { Fuelwood saved/HH/annum } \\
\text { (kg) with solar } \\
\text { water-heating system }\end{array}$ \\
\hline Summer & $3.69 \pm 0.14$ & 444.89 & $3.27 \pm 0.23$ & 401.09 \\
\hline Winter & $5.15 \pm 0.19$ & 626.54 & $6.97 \pm 0.37$ & 854.94 \\
\hline Monsoon & $4.60 \pm 0.42$ & 599.64 & $3.73 \pm 1.26$ & 457.52 \\
\hline Total & & $\begin{array}{c}1631.06 \\
31.47 \%\end{array}$ & & $\begin{array}{l}1713.55 \\
45.41 \%\end{array}$ \\
\hline
\end{tabular}

Source: HRG survey 2017-2018.

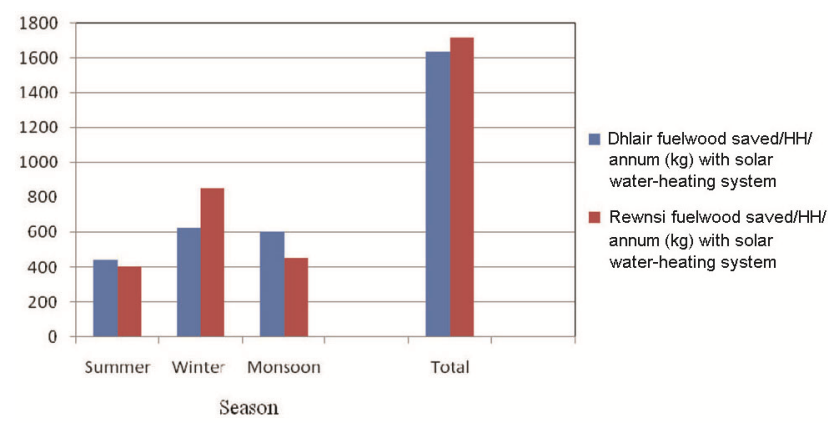

Figure 3. Fuelwood saving with solar water-heating system in three seasons.

$\mathrm{kg}$ /annum/household during different seasons. Fuelwood saving (kg/annum/household) was almost equal at both sites, but in terms of percentage savings were 31.47 and 45.41 for Kullu and Mandi sites respectively.

The main aim of the present study was to evaluate locally fabricated water-heating system to promote efficient usage of fuelwood in mountain households to achieve forest conservation, mitigation of household emission to contribute to the national agenda, to improve the status of women and generate economic avenues for rural artisans. Saving of $31.47 \%$ and $45.41 \%$ fuelwood at the two study sites was encouraging and is expected to promote such interventions in mountain households more effectively. The interventions of solar water-heating system innovation provide need-based local solutions. Similar observations and suggestions were made in earlier studies to search for simple and appropriate technology models with complete package for sustaining small-scale livelihoods in mountains focusing on resource conservation ${ }^{29,30}$.

\section{Calculated emission and mitigation of carbon with utilization of fuelwood and saving through mountain solar water system}

This being an initial study, efforts were made only to estimate $\mathrm{CO}_{2}$ emission to explain the efficiency and contribution in household emission mitigation. Potential deforestation was high with high consumption at Kullu site $\left(10.364 \mathrm{~m}^{3}\right) /$ household/annum in comparison to
Mandi $\left(7.546 \mathrm{~m}^{3}\right)$. Technology intervention was successful with estimates of direct mitigation of carbon emission (2.68 t/household/annum) at Kullu and (2.82 t/household/ annum) Mandi (Table 4). Fuelwood contributes to emissions of gases through burning and deforestation. Three fourth of the western Himalayan forest cover has been lost in the last century ${ }^{31}$. Tree species of pine and oak mainly provide fuelwood in the temperate zone and their continuous exploitation will result in loss of biodiversity, scenic beauty, soil at the place of extraction and deprive populations in the plains of drinking water and irrigation. Need-based, location-specific technology solutions as explained through installation of solar water-heating systems for rural fuelwood-dependent households in the Himalayan mountains are urgently required to reduce deforestation and mitigate household carbon emissions.

\section{Conclusion and recommendations}

Mountain households depend mainly on fuelwood for domestic energy requirements. Extraction of fuelwood is free of cost, collected by household members from natural forests. Utilization of commercial fuels like LPG, electricity and kerosene oil is restricted due to cold climate and economic conditions in the region. Fuelwood will continue to be the major source of energy in domestic sector of the Himalaya and needs immediate technology interventions like solar water-heating systems for efficient use to conserve forests and achieve sustainability. If the quantum of utilization continues with estimated volume and rate of deforestation, it will make life difficult for mountain communities. Saving with local-made mountain solar water-heating system is a good example of customizing technology to the location-specific needs and must to be encouraged through policy instruments and financial incentives for effective field popularization. This will reduce women drudgery, conserve forests, mitigate household GHGs and provide employment to rural artisans. The Indian Himalayan Region is inhabited by around 7.0 million households. Implementation of initiatives with reduction of average $2.0 \mathrm{t} \mathrm{CO}_{2}$ emission/household/annum as estimated with installation of cost-effective, locally fabricated solar water-heating 
SPECIAL SECTION:

Table 4. Calculated emission and mitigation of carbon with utilization of fuelwood and saving through mountain solar water-heating systems

\begin{tabular}{lc}
\hline Parameters & $\begin{array}{c}\text { Dhlair Jhlair, Kurpan } \\
\text { Valley, Kullu }\end{array}$ \\
\hline Fuelwood consumption/annum/HH $(\mathrm{t} \mathrm{dm})$ & 5.182 \\
Potential deforestation $\left(\mathrm{m}^{3}\right)$ contribution/HH/annum & 10.364 \\
Total carbon content $(\mathrm{t})$ in biomass burnt/HH/annum & 2.591 \\
$\mathrm{CO}_{2}$ emission from burning $(\mathrm{tCO}) / \mathrm{HH} /$ annum & 8.53 \\
$\mathrm{CO}_{2}$ mitigation with saving from mountain solar water-heating system $\left(\mathrm{tCO}_{2}\right) /$ & 2.773 \\
system/annum & 2.68 \\
\hline
\end{tabular}

system will contribute significantly to the national agenda on climate change mitigation.

1. Dhanai, R. et al., Fuel wood and fodder consumption pattern in Uttarakhand Himalayan Watershed. Int. J. Environ. Biol., 2014, 4(1), 35-40.

2. Sood, R. et al., Estimation of domestic energy consumption and carbon emission in mid-Himalayan region of Himachal Pradesh, India. J. Agric. Environ. Sci., 2014, 3, 141-147.

3. FSI, India State of Forest Report. Forest Survey of India, Ministry of Environment and Forests, Government of India, 2015.

4. UNDP, Gender Mainstreaming, A Key Driver of Development in Environment and Energy, United Nations Development Programme, New York, USA, 2007.

5. Bhatt, B. P. and Sachan, M. S., Firewood consumption along an altitudinal gradient in mountain villages of India. Biomass Bioenerg., 2004, 27, 69-75.

6. Dhanai, R. et al., Fuelwood consumption by villagers in different altitudinal gradient: a case of Takoligad watershed of Garhwal Himalaya, India. Int. J. Curr. Eng. Technol., 2015, 5(1), 72-80.

7. Kumar, S. and Kumar, M., Fuelwood consumption in Takoli Gad Watershed of Tehri Garhwal in Garhwal Himalaya, India. For. Res., 2015, 4, 138.

8. MNRE, Market assessment of solar water heating systems in the Himalayan region. Final Report submitted to Project Management Unit UNDP/GEF Assisted Global Solar Water Heating Project Submitted by Greentech Knowledge Solutions (P) Ltd, New Delhi, 2011.

9. Mospi, G., Energy Sources of Indian Households for Cooking and lighting, Report No. 567 (68/1.0/4), Ministry of Statistics and Programme Implementation, Government of India, 2012.

10. Sharma, J. V., Roadmap for achieving additional 2.5-3 billion tons $\mathrm{CO}_{2}$ sequestration from forestry sector by 2030. Policy Brief, TERI, New Delhi, 2017.

11. Holdren, J. P. and Smith, K. R., The world energy assessment: energy and the challenge of Sustainability. United Nations Development Programme, New York, 2000, pp. 61-110.

12. http://cleancookstoves.org/resources/357.html

13. FSI, India State of Forest Report. Forest Survey of India (FSI), Ministry of Environment, and Forests, 2011.

14. Campbell, J. G. and Bhattarai, T. N., People and forests in hills in Nepal. Preliminary presentation of findings of community forestry household and ward leader survey. Project Paper 10, HMG/ UNDP/FAO Community Forestry Development Project, Nepal, 1984.

15. Metz, J. J., Conservation practices at upper elevation village of the West Nepal. Mt Res. Dev., 1990, 10, 7-15.

16. Straede, S. and Treue, T., Beyond buffer zone protection: a comparative study of park and buffer zone products' importance to villagers living inside Royal Chitwan National Park and to villagers living in its buffer zone. J. Environ. Manage., 2006, 78, 251-267.

17. Singhal, et al., Forests and forestry research in India. Trop. Ecol., 2003, 44(1), 55-61.
18. World Bank, World Development Report, Sustainable Development in a Dynamic World: Transforming Institutions, Growth, and Quality of Life, Oxford University Press, New York, USA, 2003.

19. Angelsen, A. and Wunder, S., Exploring the forest poverty link: key concepts, issues and research implications, CIFOR Occasional Paper No. 40, Centre for International Forestry Research, Bogor, Indonesia, 2003.

20. FAO, Forests and poverty alleviation. In State of the World's Forests, Food and Agriculture Organization, Rome, Italy, 2003, vol. 9, pp. 61-73.

21. Sunderlin, W. D. et al., Livelihoods, forests, and conservation in developing countries: an overview. World Dev., 2005, 33(9), 1383-1402.

22. Kesari, An analysis of demand for and supply of natural resources - a case study in Mandi District. M.Phil. Dissertation Himachal Pradesh University, Shimla, 2002.

23. Kesari, Economic dependence on forest resources in Himachal Pradesh: an inter-zonal study. Ph.D. thesis, Himachal Pradesh University, Shimla, 2008.

24. Bhatt, B. P. et al., Fuel wood consumption pattern at different altitudes in Garhwal Himalaya. Energy, 1994, 19(4), 465-468.

25. World Bank, Greenhouse Gas Assessment Handbook: A Practical Guidance Document for the Assessment of Project-level Greenhouse Gas Emissions, World Bank, USA, 1998.

26. IPCC Guidelines for National Greenhouse Gas Inventories, vols. I, II and III. Intergovernmental Panel on Climate Change, United Nations Environment Program, World Meteorological Organization, Organization for Economic Co-operation and Development and International Energy Agency, 1994.

27. Rana, M. S. et al., Extraction, utilization pattern and prioritization of fuel resources for conservation in Manali Wildlife Sanctuary, Northwestern Himalaya. J. Mt. Sci., 2012, 9, 580-588.

28. Awasti, A. et al., Forest resource availability and its use by the migratory villages of Uttarkashi, Garhwal Himalaya (India). For. Ecol. Manage., 2003, 174, 13-24.

29. Samant, S. S. and Palni, L. M. S., Resource conservation as a tool for economic development. In Uttaranchal: Vision and Action Programme, Concept Publishing Company, New Delhi, 2005, pp. 242-262.

30. Palni, L. M. S. et al., Rural resource centres: need for their establishment for enhancing livelihood opportunities and ecological health in the mountains. In Mountain Technology Agenda, Status, Gaps and Possibilities, Bishen Singh Mahendra Pal Singh Press, Dehradun, 2006, pp. 280-284.

31. Joshi, P. K. et al., Forest cover assessment in western Himalayas, Himachal Pradesh using IRS1C/1DWiFS data. Curr. Sci., 2001, 80(8), 941-947.

ACKNOWLEDGEMENTS. We acknowledge financial support for conducting this study from G.B. Pant National Institute of Himalayan Environment and Sustainable Development, Almora under NMHS (Project ID NMHS/2016-17/MG16/09).

doi: $10.18520 / \mathrm{cs} / \mathrm{v} 120 / \mathrm{i} 5 / 835-840$ 